\title{
Oil Content and Fatty Acid Composition in Castor Bean Naturalized Accessions under Mediterranean Conditions in Chile
}

\author{
Celián Román-Figueroa ${ }^{1,2}$, Mara Cea ${ }^{3,4, *}$, Manuel Paneque 5 (D) and María Eugenia González ${ }^{3,4}$ \\ 1 Doctoral Program in Sciences of Natural Resources, Universidad de La Frontera, 4811230 Temuco, Chile; \\ c.roman05@ufromail.cl \\ 2 Bionostra Chile Research Foundation, San Miguel, 8900000 Santiago, Chile \\ 3 Scientific and Technological Bioresource Nucleus, BIOREN, Universidad de La Frontera, \\ 4811230 Temuco, Chile; mariaeugenia.gonzalez@ufrontera.cl \\ 4 Department of Chemical Engineering, Faculty of Engineering and Sciences, Universidad de La Frontera, \\ 4811230 Temuco, Chile \\ 5 Department of Environmental Sciences and Natural Resources, Faculty of Agricultural Sciences, \\ Universidad de Chile, La Pintana, 8820808 Santiago, Chile; mpaneque@uchile.cl \\ * Correspondence: mara.cea@ufrontera.cl
}

Received: 11 July 2020; Accepted: 4 August 2020; Published: 6 August 2020

\begin{abstract}
Castor bean is found in Chile between the Arica and Parinacota and Maule regions and is one the most important industrial crops worldwide because of the presence of ricinoleic acid in its oil. However, there is little information about it in our country. In this study, we analyzed the oil content and fatty acid profiles of 17 castor bean Chilean accessions from the Metropolitana and Valparaíso regions. The seed-oil was extracted using the Soxhlet extraction process, and the fatty acid profiles were determined using the GC-FID method. The oil content in castor bean Chilean accessions ranged between $45.7 \%$ and $54.0 \%$. Among the 17 accessions analyzed, $\mathrm{H}-15$ had the highest oil content $(54.0 \% ; p<0.05)$, whereas the $\mathrm{H}-10$ and $\mathrm{H}-08$ accessions had the lowest oil content, $(45.7 \%$ and $45.9 \%$, respectively; $p<0.05$ ). Ricinoleic acid was the most abundant fatty acid (between $87.64 \%$ and $89.83 \%$ ) in the seed-oil. The highest level of ricinoleic acid was found in the $\mathrm{H}-08$ accession. This was only statistically higher $(p<0.05)$ for three accessions, whereas the H-04 accession had the lowest ricinoleic acid content. Although the $\mathrm{H}-08$ accession registered one of the least abundant oil contents, it had the highest amount of ricinoleic acid. No significant correlation was found between oil content and ricinoleic acid. Our study suggests that oil content does not influence the castor oil fatty profile. The high oil content and ricinoleic acid level registered in castor bean Chilean accessions justify their production in Chile and their utilization for developing bio-based products. Furthermore, Chilean castor bean could grow in semi-arid lands. However, further field studies are needed to identify the cultivars best suited for Mediterranean conditions.
\end{abstract}

Keywords: castor oil; industrial crops; Mediterranean climate; vegetable seed-oil; Ricinus communis L.

\section{Introduction}

Castor bean (Ricinus communis L.) is one the most important industrial crops in the world due to the commercial importance of its oil [1]. Castor plants grow in tropical climates [2], with high annual rainfall (over $400 \mathrm{~mm}$ year ${ }^{-1}$ ) and high annual average temperature (between $20-27^{\circ} \mathrm{C}$ ) $[2,3]$. Despite this, castor bean has been introduced and adapted to the varying climatic conditions in many countries, including Chile, where it is wildly growing $[4,5]$. 
In Chile, the castor bean is found between the Arica and Parinacota and Maule regions (unpublished), growing under arid and semi-arid conditions and in Mediterranean climates. Those areas normally receive an annual average rainfall lower than $400 \mathrm{~mm}$ that is concentrated during the winter season, and in some areas the rainfall is even below $50 \mathrm{~mm}$. Meanwhile, the annual average temperature is lower than $20^{\circ} \mathrm{C}$ [6]. Therefore, these naturalized castor beans have shown high adaptability to Chilean climatic conditions. However, there is little information regarding the use, adaptation, and characterization of castor bean and castor oil in Chile $[4,5]$.

Seed-oil content in castor bean is variable according to germplasms or accessions, ranging between $28 \%$ and $59 \%[7,8]$. This inedible oil contains ricinoleic acid, which constitutes $79 \%$ to $92 \%$ of the fatty acid content in the seed-oil [7,8]. Castor oil is considered a high-value oil for the agriculture, medicine, and cosmetic sectors because ricinoleic acid can be chemically transformed to obtain various commercial products of interest, such as lubricants, inks, biopolymers, and biodiesel [8]. Moreover, it is considered as a second-generation raw material for the production of bioenergy or industrial purposes [9].

Although castor bean cultivars are mostly adapted to tropical conditions $[8,10]$, their growth has also been evaluated in semi-arid conditions of Mediterranean climates [2,3,11,12]. There are two dwarf cultivars, "Hale" and "Brigham", developed in the USA, that can grow under semi-arid or arid conditions, with a maximum oil yield of $47.8 \%$ [10,13]. An evaluation of adventive germplasms growing under Mediterranean conditions would allow their potential use for breeding programs and thereby help to obtain new cultivars [12]. Moreover, castor bean production in marginal land has been promoted as an alternative to avoid competition with food and feed production [2,11], and castor bean is one of the industrial crops most attractive for seed-oil production under arid and semi-arid conditions [2].

Castor bean can be used as a productive alternative crop in arid or semi-arid land; however, identifying and procuring cultivars that can adapt to these conditions is a key factor for the success of such ventures. Thus, the evaluation of the oil contents and fatty acid composition of the wild germplasms including Chilean castor bean accessions, may contribute towards this purpose. Therefore, the objective of this study was to evaluate the oil content and fatty acid composition of Chilean castor accessions that wildly grow in Chilean climatic conditions to be used as potential industrial crops in a Mediterranean climate.

\section{Materials and Methods}

Seventeen castor bean naturalized accessions of Chile, obtained in January 2018 from a germplasm field of the Faculty of Agronomic Sciences of Universidad de Chile ( $33^{\circ} 34^{\prime} 05^{\prime \prime}$ S, $70^{\circ} 38^{\prime} 04^{\prime \prime}$ W), were evaluated. The detailed collection site of 17 castor accessions is presented (Table 1). A germplasm field was established with one accession per row and spacing of $1.0 \mathrm{~m}$ between plants within a row and $1.5 \mathrm{~m}$ between rows. Weeds were controlled manually, and no fertilizer or pesticide was applied. The racemes were also collected by hand. All accessions growing as adventive species were collected from Valparaíso and Metropolitana regions.

The seeds of castor bean were milled and dried in an oven overnight at $105^{\circ} \mathrm{C}$ until reaching a constant weight. Oil was extracted using the Soxhlet system with hexane as a solvent for 30 cycles (or $5 \mathrm{~h}$ ), and it was recovered through evaporation as described by Perdomo et al. [14].

The fatty acid composition was determined according to Hidalgo et al. [15]. Briefly, $50 \mu \mathrm{L}$ of castor oil was hydrolyzed with $1.0 \mathrm{~mL}$ of potassium hydroxide/methanol solution $(0.5 \mathrm{M})$ at $100{ }^{\circ} \mathrm{C}$ for $5 \mathrm{~min}$. After $400 \mu \mathrm{L}$ of a methylation solution comprising hydrochloric acid in methanol $(4: 1 \mathrm{v} / \mathrm{v})$ was added, it was maintained at $100{ }^{\circ} \mathrm{C}$ for $15 \mathrm{~min}$. The sample was cooled, and $2.0 \mathrm{~mL}$ of purified water and $3.0 \mathrm{~mL}$ petroleum ether were added and then stirred vigorously and allowed to stand for 1 min until two phases clearly separated; then, the supernatant was used for the downstream processes. Finally, petroleum ether from the supernatant was evaporated at $55^{\circ} \mathrm{C}$. Gas chromatography with flame-ionization detector (GC-FID) was employed for fatty acid analysis (Clarus 600, PerkinElmer, 
Waltham, MA, USA). The samples for GC-FID were prepared in a vial, where $10 \mu \mathrm{L}$ of methylated castor oil was dissolved in $233 \mu \mathrm{L}$ of methyl heptadecanoate (internal standard) and $926 \mu \mathrm{L}$ of heptane. The vial was closed with a teflon septa cap and shaken vigorously, and $0.5 \mu \mathrm{L}$ was injected. A capillary column ( $30 \mathrm{~m} \times 0.53 \mathrm{~mm} \times 0.5 \mu \mathrm{m}$; DB23, J\&W Scientific, Folsom, CA, USA) was used with helium as a carrier gas $\left(5.0 \mathrm{~mL} \mathrm{~min}^{-1}\right)$. The injector and detector temperatures were $250{ }^{\circ} \mathrm{C}$, while the oven temperature was at a gradient: $60^{\circ} \mathrm{C}$ to $180^{\circ} \mathrm{C}$ at $30^{\circ} \mathrm{C} \mathrm{min}-1$ and then from $180{ }^{\circ} \mathrm{C}$ to $210{ }^{\circ} \mathrm{C}$ at $2{ }^{\circ} \mathrm{C} \mathrm{min}-1$. Fatty acids peaks were identified by comparison with the relative retention time of fatty acids methyl esters standard (Sigma-Aldrich Co., St. Louis, MO, USA).

Table 1. Castor bean Chilean accessions evaluated in this study.

\begin{tabular}{|c|c|c|c|c|c|}
\hline Accessions & Locality, Region & Coordinate & Accessions & Locality, Region & Coordinate \\
\hline H-01 & $\begin{array}{l}\text { Cerro Blanco, } \\
\text { Metropolitana }\end{array}$ & $\begin{array}{l}33^{\circ} 24^{\prime} 59^{\prime \prime} \mathrm{S} \\
70^{\circ} 38^{\prime} 40^{\prime \prime} \mathrm{W}\end{array}$ & $\mathrm{H}-10$ & $\begin{array}{l}\text { Talagante (Green), } \\
\text { Metropolitana }\end{array}$ & $\begin{array}{l}33^{\circ} 40^{\prime} 59^{\prime \prime} \mathrm{S} \\
70^{\circ} 57^{\prime} 34^{\prime \prime} \mathrm{W}\end{array}$ \\
\hline $\mathrm{H}-02$ & $\begin{array}{l}\text { Cerro San Cristóbal, } \\
\text { Metropolitana }\end{array}$ & $\begin{array}{l}33^{\circ} 25^{\prime} 31^{\prime \prime} \mathrm{S} \\
70^{\circ} 38^{\prime} 01^{\prime \prime} \mathrm{W}\end{array}$ & H-12 & $\begin{array}{l}\text { Gran Avenida, } \\
\text { Metropolitana }\end{array}$ & $\begin{array}{l}33^{\circ} 32^{\prime} 29^{\prime \prime} \mathrm{S} \\
70^{\circ} 40^{\prime} 00^{\prime \prime} \mathrm{W}\end{array}$ \\
\hline $\mathrm{H}-03$ & $\begin{array}{l}\text { Cantera del Monte, } \\
\text { Metropolitana }\end{array}$ & $\begin{array}{l}33^{\circ} 40^{\prime} 30^{\prime \prime} \mathrm{S} \\
70^{\circ} 59^{\prime} 52^{\prime \prime} \mathrm{W}\end{array}$ & H-14 & Muelle Barón, Valparaíso & $\begin{array}{l}33^{\circ} 02^{\prime} 33^{\prime \prime} \mathrm{S} \\
71^{\circ} 36^{\prime} 22^{\prime \prime} \mathrm{W}\end{array}$ \\
\hline H-04 & $\begin{array}{c}\text { San Francisco del } \\
\text { Monte, } \\
\text { Metropolitana }\end{array}$ & $\begin{array}{l}33^{\circ} 40^{\prime} 56^{\prime \prime} \mathrm{S} \\
70^{\circ} 58^{\prime} 34^{\prime \prime} \mathrm{W}\end{array}$ & H-15 & $\begin{array}{l}\text { Cerro Jiménez, } \\
\text { Valparaíso }\end{array}$ & $\begin{array}{l}33^{\circ} 03^{\prime} 02^{\prime \prime} \mathrm{S} \\
71^{\circ} 37^{\prime} 47^{\prime \prime} \mathrm{W}\end{array}$ \\
\hline H-05 & $\begin{array}{l}\text { Puente Rinconada, } \\
\text { Metropolitana }\end{array}$ & $\begin{array}{l}33^{\circ} 30^{\prime} 25^{\prime \prime} \mathrm{S} \\
70^{\circ} 48^{\prime} 20^{\prime \prime} \mathrm{W}\end{array}$ & $\mathrm{H}-16$ & $\begin{array}{l}\text { Isla de Pascua, } \\
\text { Valparaíso }\end{array}$ & $\begin{array}{c}27^{\circ} 08^{\prime} 59^{\prime \prime} \mathrm{S} \\
109^{\circ} 26^{\prime} 20^{\prime \prime} \mathrm{W}\end{array}$ \\
\hline $\mathrm{H}-06$ & $\begin{array}{l}\text { Talagante (Red), } \\
\text { Metropolitana }\end{array}$ & $\begin{array}{l}33^{\circ} 40^{\prime} 12^{\prime \prime} \mathrm{S} \\
70^{\circ} 56^{\prime} 27^{\prime \prime} \mathrm{W}\end{array}$ & H-17 & Chilca, Valparaíso & $\begin{array}{l}32^{\circ} 51^{\prime} 05^{\prime \prime} \mathrm{S} \\
70^{\circ} 52^{\prime} 53^{\prime \prime} \mathrm{W}\end{array}$ \\
\hline $\mathrm{H}-07$ & Petorca, Valparaíso & $\begin{array}{l}32^{\circ} 15^{\prime} 01^{\prime \prime} \mathrm{S} \\
70^{\circ} 55^{\prime} 53^{\prime \prime} \mathrm{W}\end{array}$ & $\mathrm{H}-18$ & $\begin{array}{l}\text { Universidad Adolfo } \\
\text { Ibáñez, Metropolitana }\end{array}$ & $\begin{array}{l}33^{\circ} 29^{\prime} 22^{\prime \prime} \mathrm{S} \\
70^{\circ} 31^{\prime} 09^{\prime \prime} \mathrm{W}\end{array}$ \\
\hline $\mathrm{H}-08$ & $\begin{array}{l}\text { Cuyuncaví, } \\
\text { Metropolitana }\end{array}$ & $\begin{array}{l}33^{\circ} 24^{\prime} 32^{\prime \prime} \mathrm{S} \\
70^{\circ} 07^{\prime} 36^{\prime \prime} \mathrm{W}\end{array}$ & H-19 & $\begin{array}{l}\text { Autopista del Sol, } \\
\text { Metropolitana }\end{array}$ & $\begin{array}{l}33^{\circ} 29^{\prime} 17^{\prime \prime} \mathrm{S} \\
70^{\circ} 44^{\prime} 50^{\prime \prime} \mathrm{W}\end{array}$ \\
\hline H-09 & $\begin{array}{l}\text { Zanjón de la Aguada, } \\
\text { Metropolitana }\end{array}$ & $\begin{array}{l}33^{\circ} 28^{\prime} 50^{\prime \prime} \mathrm{S} \\
70^{\circ} 37^{\prime} 51^{\prime \prime} \mathrm{W}\end{array}$ & & & \\
\hline
\end{tabular}

Data of oil content and fatty acid composition were evaluated for normality and variance homogeneity using the Kolmogorov-Smirnov and Levene's tests, respectively. Analysis of variance was performed, and the averages were compared using a Tukey's test to determine significant differences between the groups. Statistical significance was defined as $p<0.05$. SPSS software, version 25.0, was used for statistical analyses. All analyses were made with three replicates. Additionally, correlation analysis was performed to determine the relationship between oil content and fatty acids present in castor oil.

\section{Results}

The oil content in the different Chilean castor bean accessions, from Valparaíso and Metropolitana regions, ranged from $45.7 \%$ to $54.0 \%$ of the total seed-oil, with an average of $49.2 \%$ (Figure 1 ). The maximum castor oil content was registered for the H-15 accession (54.0\%), whereas H-10 (45.7\%) and H-08 (45.9\%) showed the lowest oil content among the tested accessions (Figure 1). The difference between the castor oil content in $\mathrm{H}-15$ and that in the other accessions, except $\mathrm{H}-02, \mathrm{H}-09$, and $\mathrm{H}-14$, was statistically significant $(p<0.05)$. However, the minimum amount of castor oil was statistically significant $(p<0.05)$ for 11 accessions (Figure 1$)$.

Ricinoleic acid $(\mathrm{C} 18: 1-\mathrm{OH})$ content in Chilean castor accessions was in the range of $87.6 \%$ to $89.8 \%$, in $\mathrm{H}-04$ and $\mathrm{H}-08$ accessions, respectively. Linoleic, oleic, stearic, palmitic, and linolenic acids (in order of decreasing content) were also detected. The ricinoleic acid content in Chilean accessions did not vary between the different accessions; the maximum content (89.8\%) was detected in the H-08 accession, and this was not statistically significant for 13 of 16 accessions (Table 2). 
Table 2. Fatty acids profile of seventeen castor bean Chilean accessions.

\begin{tabular}{|c|c|c|c|c|c|c|}
\hline \multicolumn{7}{|c|}{ Fatty Acid Content (\%) } \\
\hline & C16:00 & C18:00 & C18:1 & C18:2 & C18:3 & C18:1-OH \\
\hline $\mathrm{H}-01$ & $1.06( \pm 0.03)^{b}$ & $1.24( \pm 0.03)^{\mathrm{c}, \mathrm{d}, \mathrm{e}}$ & $2.71( \pm 0.03)^{h}$ & $4.90( \pm 0.06)^{a, b, c}$ & $0.47( \pm 0.01)^{\mathrm{a}, \mathrm{b}, \mathrm{c}}$ & $89.55( \pm 0.08)^{a, b}$ \\
\hline $\mathrm{H}-02$ & $1.18( \pm 0.11)^{\mathrm{a}, \mathrm{b}}$ & $1.47 \pm(0.06)^{a, b, c}$ & $3.16( \pm 0.03)^{f, g}$ & $4.84( \pm 0.05)^{a, b, c}$ & $0.40( \pm 0.01)^{e, f, g}$ & $88.86( \pm 0.25)^{a, b, c, d}$ \\
\hline $\mathrm{H}-03$ & $1.31( \pm 0.01)^{\mathrm{a}}$ & $1.26( \pm 0.00)^{b, c, d, e}$ & $3.60( \pm 0.01)^{a, b, c, d, e}$ & $5.12( \pm 0.06)^{\mathrm{a}}$ & $0.49( \pm 0.01)^{\mathrm{a}}$ & $88.16( \pm 0.07)^{\mathrm{c}, \mathrm{d}}$ \\
\hline $\mathrm{H}-04$ & $1.30( \pm 0.02)^{\mathrm{a}}$ & $1.51( \pm 0.04)^{a, b}$ & $4.01( \pm 0.04)^{\mathrm{a}}$ & $5.04( \pm 0.06)^{a, b}$ & $0.50( \pm 0.02)^{\mathrm{a}}$ & $87.64( \pm 0.07)^{\mathrm{d}}$ \\
\hline H-05 & $1.16( \pm 0.04)^{\mathrm{a}, \mathrm{b}}$ & $1.20( \pm 0.05) \mathrm{d}, \mathrm{e}$ & $3.67( \pm 0.08)^{a, b, c}$ & $4.78( \pm 0.04)^{\mathrm{a}, \mathrm{b}, \mathrm{c}, \mathrm{d}}$ & $0.50( \pm 0.02)^{\mathrm{a}}$ & $88.66( \pm 0.12)^{a, b, c, d}$ \\
\hline H-06 & $1.12( \pm 0.10)^{a, b}$ & $1.36( \pm 0.08)^{a, b, c, d}$ & $3.22( \pm 0.12)^{d, e, f, g}$ & $4.74( \pm 0.18)^{\mathrm{a}, \mathrm{b}, \mathrm{c}, \mathrm{d}}$ & $0.43( \pm 0.01)^{\mathrm{c}, \mathrm{d}, \mathrm{e}, \mathrm{f}}$ & $89.05( \pm 0.49)^{a, b, c}$ \\
\hline $\mathrm{H}-07$ & $1.11( \pm 0.04)^{a, b}$ & $1.21( \pm 0.03)^{c, d, e}$ & $3.28( \pm 0.05)^{b, c, d, e, f, g}$ & $4.77( \pm 0.05)^{a, b, c, d}$ & $0.50( \pm 0.01)^{\mathrm{a}}$ & $89.05( \pm 0.16)^{a, b, c}$ \\
\hline $\mathrm{H}-08$ & $1.07( \pm 0.09)^{b}$ & $1.22( \pm 0.16)^{c, d, e}$ & $3.28( \pm 0.31)^{b, c, d, e, f, g}$ & $4.14( \pm 0.05)^{\mathrm{e}}$ & $0.41( \pm 0.02) \mathrm{d}, \mathrm{e}, \mathrm{f}, \mathrm{g}$ & $89.83( \pm 0.65)^{a}$ \\
\hline H-09 & $1.03( \pm 0.06)^{b}$ & $1.27( \pm 0.13)^{a, b, c, d, e}$ & $3.03( \pm 0.21)^{g, h}$ & $4.49( \pm 0.07)^{c, d, e}$ & $0.39( \pm 0.02)^{f, g}$ & $89.71( \pm 0.70)^{a, b}$ \\
\hline $\mathrm{H}-10$ & $1.12( \pm 0.06)^{a, b}$ & $1.18( \pm 0.11) \mathrm{d}, \mathrm{e}, \mathrm{f}$ & $3.40( \pm 0.23)^{b, c, d, e, f, g}$ & $4.60( \pm 0.23)^{c, d}$ & $0.43( \pm 0.02)^{c, d, e, f}$ & $89.24( \pm 0.68)^{a, b, c}$ \\
\hline $\mathrm{H}-12$ & $1.14( \pm 0.03)^{a, b}$ & $1.05( \pm 0.02) \mathrm{e}, \mathrm{f}$ & $3.68( \pm 0.06)^{a, b}$ & $5.08( \pm 0.08)^{a}$ & $0.44( \pm 0.01)^{b, c, d, e}$ & $88.58( \pm 0.14)^{b, c, d}$ \\
\hline H-14 & $1.11( \pm 0.01)^{a, b}$ & $1.32( \pm 0.02)^{a, b, c, d}$ & $3.52( \pm 0.03)^{b, c, d, e, f}$ & $4.39( \pm 0.13)^{\mathrm{d}, \mathrm{e}}$ & $0.46( \pm 0.02)^{a, b, c, d}$ & $89.15( \pm 0.20)^{a, b, c}$ \\
\hline H-15 & $1.06( \pm 0.01)^{b}$ & $1.35( \pm 0.01)^{a, b, c, d}$ & $3.21( \pm 0.01)^{e, f, g}$ & $4.63( \pm 0.10)^{b, c, d}$ & $0.38( \pm 0.02)^{\mathrm{g}}$ & $89.32( \pm 0.15)^{a, b, c}$ \\
\hline H-16 & $1.11( \pm 0.15)^{\mathrm{a}, \mathrm{b}}$ & $0.94( \pm 0.13)^{\mathrm{f}}$ & $3.64( \pm 0.11) a, b, c, d$ & $4.83( \pm 0.26)^{a, b, c}$ & $0.47( \pm 0.04)^{\mathrm{a}, \mathrm{b}, \mathrm{c}}$ & $88.94( \pm 0.57)^{a, b, c}$ \\
\hline $\mathrm{H}-17$ & $1.04( \pm 0.02)^{b}$ & $1.20( \pm 0.04)^{\mathrm{d}, \mathrm{e}}$ & $3.30( \pm 0.06)^{b, c, d, e, f, g}$ & $4.60( \pm 0.09)^{\mathrm{c}, \mathrm{d}}$ & $0.46( \pm 0.01)^{a, b, c, d}$ & $89.32( \pm 0.22)^{a, b, c}$ \\
\hline H-18 & $1.13( \pm 0.11)^{\mathrm{a}, \mathrm{b}}$ & $1.53( \pm 0.18)^{\mathrm{a}}$ & $3.40( \pm 0.30)^{b, c, d, e, f, g}$ & $4.70( \pm 0.18)^{a, b, c, d}$ & $0.37( \pm 0.01)^{g}$ & $88.81( \pm 0.73)^{a, b, c, d}$ \\
\hline H-19 & $1.23( \pm 0.04)^{a, b}$ & $1.32( \pm 0.04)^{a, b, c, d}$ & $3.25( \pm 0.08)^{c, d, e, f, g}$ & $4.82( \pm 0.07)^{\mathrm{a}, \mathrm{b}, \mathrm{c}, \mathrm{d}}$ & $0.48( \pm 0.01)^{\mathrm{a}, \mathrm{b}}$ & $88.79( \pm 0.25)^{a, b, c, d}$ \\
\hline
\end{tabular}

Different lowercase letters in the same columns are significantly different $(p<0.05 ; \mathrm{n}=3$ ); values are expressed as mean \pm standard deviation ( $\mathrm{n}=3$ ). C16:0: palmitic acid; C18:0: stearic acid; C18:1: oleic acid; C18:2: linoleic acid; C18:3: linolenic acid; C18:1-OH: ricinoleic acid. 


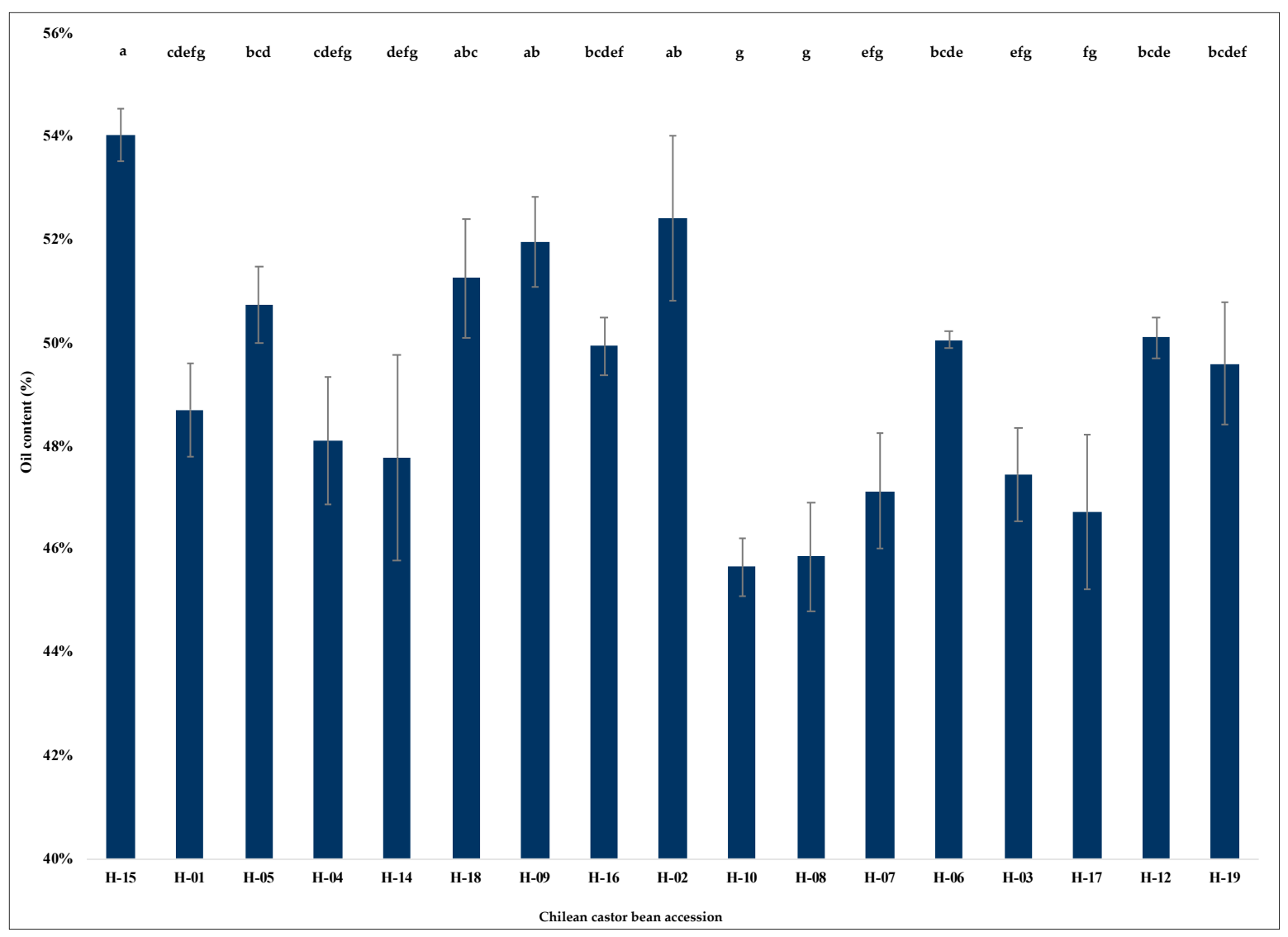

Figure 1. Castor bean seed-oil content in different Chilean accessions. Oil content (\%) corresponds to the mean for three replicates. Vertical bars represent standard error of the mean $(n=3)$, and different lowercase letters in the columns represent statistically significant differences $(p<0.05)$.

Furthermore, there was no significant correlation observed between oil and ricinoleic acid content $(\mathrm{r}=-0.013 ; p>0.01)$. Meanwhile, linolenic acid was the only fatty acid that showed a moderately significant correlation with oil content $(\mathrm{r}=-0.432 ; p<0.01)$. However, it was the least abundant fatty acid in castor oil (average of $0.5 \%$ ). Moreover, there was a significantly negative correlation between ricinoleic acid and the other fatty acids, especially palmitic $(\mathrm{r}=-0.870 ; p<0.01)$, oleic $(\mathrm{r}=-0.789$; $p<0.01)$, and linoleic acids $(\mathrm{r}=-0.785 ; p<0.01$; Table 3$)$.

Table 3. Pearson correlation coefficients comparing oil content (\%) and fatty acid content (\%) registered in the 17 castor Chilean accessions.

\begin{tabular}{|c|c|c|c|c|c|c|c|}
\hline & & C16:0 & C18:0 & C18:1 & C18:2 & C18:3 & C18:1-OH \\
\hline \multirow[t]{2}{*}{ Oil content } & Pearson correlation & -0.098 & 0.224 & -0.165 & 0.163 & $-0.432 *$ & -0.013 \\
\hline & Sig. ( $p$ value) & 0.496 & 0.113 & 0.246 & 0.252 & 0.002 & 0.927 \\
\hline \multirow[t]{2}{*}{ C16:0 } & Pearson correlation & & 0.445 * & 0.628 * & 0.612 * & $0.406^{*}$ & -0.870 * \\
\hline & Sig. ( $p$ value) & & 0.001 & 0 & 0 & 0.003 & 0 \\
\hline \multirow[t]{2}{*}{ C18:0 } & Pearson correlation & & & 0.087 & 0.116 & -0.254 & $-0.410 *$ \\
\hline & Sig. ( $p$ value) & & & 0.543 & 0.417 & 0.072 & 0.003 \\
\hline \multirow[t]{2}{*}{ C18:1 } & Pearson correlation & & & & 0.385 * & 0.396 * & $-0.789 *$ \\
\hline & Sig. ( $p$ value) & & & & 0.005 & 0.004 & 0 \\
\hline \multirow[t]{2}{*}{ C18:2 } & Pearson correlation & & & & & $0.492 *$ & $-0.785 *$ \\
\hline & Sig. ( $p$ value) & & & & & 0 & 0 \\
\hline \multirow[t]{2}{*}{ C18:3 } & Pearson correlation & & & & & & $-0.474 *$ \\
\hline & Sig. ( $p$ value) & & & & & & 0 \\
\hline
\end{tabular}

* Significative correlation at 0.01 level. C16:0: palmitic acid; C18:0: stearic acid; C18:1: oleic acid; C18:2: linoleic acid; C18:3: linolenic acid; C18:1-OH: ricinoleic acid. 


\section{Discussion}

In this study, castor oil content in the Chilean accessions was found to range between $45.7 \%$ and $54.0 \%$ (Figure 1). According to the literature, oil content in castor bean seed ranges from $38 \%$ to $55 \%$ in an Indian collection [8] and from $36.6 \%$ to $49.2 \%$ in Chinese accessions [16]. In the USDA collection, the maximum oil contents reported in two different studies were $56.5 \%$ [7] and 60.6\% [17]. In the present study, seven accessions showed castor oil contents greater than $50 \%(\mathrm{H}-06, \mathrm{H}-12, \mathrm{H}-05, \mathrm{H}-18$, H-09, H-02, and H-15; Figure 1).

Under natural conditions, the average oil content in castor bean fluctuates between $42.0 \%$ and $49.0 \%$ [8] but reaches between $47.0 \%$ and $55.0 \%$ under Mediterranean conditions [3,11,12]. Sixteen Chilean castor bean accessions in this study were collected from a Mediterranean climate [6], except H-16, which was obtained from Rapa Nui with an annual average rainfall of $1157 \mathrm{~mm}_{\text {year }}{ }^{-1}$ and mean temperature between 18 to $20^{\circ} \mathrm{C}$ [18], and the oil content for these averaged $49.2 \%$ (Figure 1). These results could indicate that the oil content in castor bean accessions grown in Mediterranean conditions could be superior to that of plants grown in natural conditions (tropical climate), despite precipitation during 2017 being $343 \mathrm{~mm}$ in Cardenal Zamoré meteorology station $\left(33^{\circ} 31^{\prime} \mathrm{S}\right.$, $70^{\circ} 35^{\prime} \mathrm{W}$ ) [19], which was considerably lower than the precipitation level considered as optimal for castor bean growth $(>750 \mathrm{~mm})$ [20]. This is despite the fact that plants under stress conditions normally have reduced oil contents in oilseeds [21]. Therefore, these results suggest that these accessions have completely adapted to the Mediterranean climate. Regardless, oil content and fatty acid profiles in oilseeds are dependent on genotype, environmental conditions, and their interactions [21]; however, more information (agronomic, genetic, and physiologic) is necessary to determine castor bean oil production and yield under Chilean conditions.

On the contrary, the castor bean vulnerability to freeze stress (low sub-zero temperature) has been previously reported $[8,22]$, and there is limited information about castor bean cultivars adapted to these conditions of abiotic stress. Castor bean naturalized accessions under Mediterranean conditions in Chile are exposed to a freezing temperature for at least 8.0 days per year [23]; thus, these results suggest the possibility of developing a cultivar adapted to frost stress in countries with Mediterranean climates. Precisely, some of the most important challenges for increasing castor bean production worldwide are germplasm evaluation, breeding programs, and abiotic stress of cultivars [24], and with these results, it could be assumed that Chilean castor bean accessions could tolerate mild frost and maintain high seed-oil production.

The fatty acid profiles obtained for all Chilean castor beans evaluated in this study were similar to those previously registered by Zapata et al. [4] and Román-Figueroa et al. [5] in Chilean accessions. The ricinoleic acid content (average of $88.9 \%$ ) registered in castor bean Chilean accessions was higher than that previously reported in USDA castor germplasms $(84.5 \%)$, as well as Tunisian $(81.8 \%)$ and Spanish $(87.6 \%)$ accessions $[11,12,25]$. This high ricinoleic acid content in Chilean accessions could be an opportunity to obtain a cultivar adapted to Mediterranean conditions, but further field evaluations of the accessions with the highest oil or ricinoleic acid contents characterized in this study could lead to obtaining commercial cultivars. However, there were no correlations between castor oil and ricinoleic acid; therefore, high oil content does not guarantee high ricinoleic acid content in the fatty acid profile.

In fact, in this study, it was observed that the H-08 accession, which had the second lowest oil content (45.9\%) among the Chilean accessions (Figure 1), had the highest ricinoleic acid content $(89.8 \%$; Table 2). Meanwhile, the only significant correlation between oil and some fatty acid content was registered with linolenic acid, but this fatty acid is found in lower quantities in the castor bean seed. Consequently, its variation did not have an impact on castor oil content and fatty acid profiles [25,26].

Significant correlation was not found between ricinoleic acid and oil content in Chilean castor bean (Table 3), this might be due to the relative quantification method for fatty acids determination employed in this study [27]. Anyway, similar to the present observations, previous studies also did not find significant correlations [25,26,28]. In contrast, Huang et al. [16] and Velasco et al. [12] found a positive correlation between oil content and ricinoleic acid, whereas Anastasi et al. [11] observed a 
highly significant negative correlation. These contradicting results hint at the high genetic variability among castor bean accessions. This highlights the importance of establishing a breeding program to obtain cultivars with homogenous characteristics $[29,30]$.

This inverse correlation could be explained by the fact that in the synthesis of ricinoleic acid, oleic acid must be hydroxylated, and hence, when ricinoleic acid content increases, oleic acid content is reduced in the seed-oil [31]. Likewise, this behavior would result in decreased linoleic acid, which is also synthesized from oleic acid [32]. Similar correlations were observed by Da Silva et al. [26], Wang et al. [25], Shah et al. [28], and Anastasi et al. [11]. However, Huang et al. [14] did not detect significant correlations between ricinoleic acid and other fatty acids.

\section{Conclusions}

Chilean castor accessions showed high seed oil content (49.2\%). The H-15 accession had the highest oil content $(54.0 \%)$, which was greater than that of some commercial castor cultivars from other countries. On the contrary, the castor oil fatty acid profile was similar to those previously published and included ricinoleic, linolenic, linoleic, oleic, stearic, and palmitic acids.

As was expected, ricinoleic acid was the most important fatty acid in the Chilean castor accessions (ranged between $87.6 \%$ and $89.8 \%$ ), and its concentration was not related to oil content. The H-08 accession showed one the lowest oil contents (45.9\%) but the highest ricinoleic acid content $(89.83 \%)$ among the seventeen accessions evaluated. These results confirmed that there is no direct correlation between oil content and ricinoleic acid.

The characteristics of Chilean castor bean accessions related to oil content and fatty profile need to be further studied, and the interaction of genotype $\times$ environment needs to be evaluated for the determination of seed productivity and oil yield in field experiments and for a breeding program to obtain a castor bean Chilean cultivar.

Author Contributions: C.R.-F.: conceptualization, methodology, investigation, resources, formal analysis, writing-original draft, visualization. M.C.: conceptualization, resources, writing-review and editing, supervision. M.E.G.: writing-review and editing. M.P.: resources, writing-review and editing, resources. All authors have read and agreed to the published version of the manuscript.

Funding: This research was funded by ANID via financial support from ANID/Beca Doctorado Nacional/2018-21181539, funding was also provided to Universidad de La Frontera via financial support through DIUFRO DI19-1003 and CONICYT PIA ACT172128 projects, and Agroenergía Ingeniería Genética S.A.

Conflicts of Interest: The authors declare no conflict of interest.

\section{References}

1. Rios, I.C.; Cordeiro, J.P.; Arruda, T.B.M.G.; Rodrigues, F.E.A.; Uchoa, A.F.J.; Luna, F.M.T.; Cavalcante, C.L., Jr.; Ricardo, N.M.P.S. Chemical modification of castor oil fatty acids (Ricinus communis) for biolubricant applications: An alternative for Brazil's green market. Ind. Crop. Prod. 2020, 145, 112000. [CrossRef]

2. Patanè, C.; Cosentino, S.L.; Corinzia, S.A.; Testa, G.; Sortino, O.; Scordia, D. Photothermal zoning of castor (Ricinus communis L.) growing season in the semi-arid Mediterranean area. Ind. Crop. Prod. 2019, 142, 111837. [CrossRef]

3. Zanetti, F.; Chieco, C.; Alexopoulou, E.; Vecchi, A.; Bertazza, G.; Monti, A. Comparison of new castor (Ricinus communis L.) genotypes in the mediterranean area and possible valorization of residual biomass for insect rearing. Ind. Crop. Prod. 2017, 107, 581-587. [CrossRef]

4. Zapata, N.; Vargas, M.; Reyes, J.F.M.; Belmar, G. Quality of biodiesel and press cake obtained from Euphorbia lathyris, Brassica napus and Ricinus communis. Ind. Crop. Prod. 2012, 38, 1-5. [CrossRef]

5. Román-Figueroa, C.; Olivares-Carrillo, P.; Paneque, M.; Palacios-Nereo, F.; Quesada-Medina, J. High-yield production of biodiesel by non-catalytic supercritical methanol transesterification of crude castor oil (Ricinus communis). Energy 2016, 107, 165-171. [CrossRef]

6. Sarricolea, P.M.; Herrera-Ossandón, M.; Meseguer-Ruiz, O. Climatic regionalisation of continental Chile. J. Maps 2017, 13, 66-73. [CrossRef] 
7. Rojas-Barros, P.; de Haro, A.; Muñoz, J.; Fernández-Martínez, J.M. Isolation of a natural 183 mutant in Castor with high oleic/low ricinoleic acid content in the oil. Crop. Sci. 2004, 44, 76-80. [CrossRef]

8. Anjani, K. Castor genetic resources: A primary gene pool for exploitation. Ind. Crop. Prod. 2012, 35, 1-4. [CrossRef]

9. Román-Figueroa, C.; Paneque, M. Ethics and biofuel production in Chile. J. Agric. Environ. Ethic. 2015, 28, 293-312. [CrossRef]

10. Severino, L.S.; Auld, D.L. Seed yield and yield components of castor influenced by irrigation. Ind. Crop. Prod. 2013, 49, 52-60. [CrossRef]

11. Anastasi, U.; Sortino, O.; Cosentino, S.L.; Patanè, C. Seed yield and oil quality of perennial castor bean in a Mediterranean environment. Int. J. Plant Prod. 2015, 9, 99-116. [CrossRef]

12. Velasco, L.; Fernández-Cuesta, Á.; Pascual-Villalobos, M.J.; Fernández-Martínez, J.M. Variability of seed quality traits in wild and semi-wild accessions of castor collected in Spain. Ind. Crop. Prod. 2015, 65, $203-209$. [CrossRef]

13. Campbell, D.N.; Rowland, D.L.; Schnell, R.W.; Ferrell, J.A.; Wilkie, A.N. Developing a castor (Ricinus communis L.) production system in Florida, U.S.: Evaluating crop phenology and response to management. Ind. Crop. Prod. 2014, 53, 217-227. [CrossRef]

14. Perdomo, F.A.; Acosta-Osorio, A.A.; Herrera, G.; Vasco-Leal, J.F.; Mosquera-Artamonov, J.D.; Millan-Malo, B.; Rodríguez-García, M.E. Physicochemical characterization of seven Mexican Ricinus communis L. seeds and oil contents. Biomass Bioenerg. 2013, 48, 17-24. [CrossRef]

15. Hidalgo, P.; Navia, R.; Hunter, R.; González, M.E.; Echeverría, A. Development of novel bio-based epoxides from microalgae Nannochloropsis gaditana lipids. Compos. Part B Eng. 2019, 166, 653-662. [CrossRef]

16. Huang, F.; Bao, C.; Peng, M.; Zhu, G.; He, Z.; Chen, X.; Luo, R.; Zhao, Y. Chromatographic analysis of fatty acid composition in differently sized seeds of castor accessions. Biotechnol. Biotech. Eq. 2015, 29, 892-900. [CrossRef]

17. Wang, M.L.; Morris, J.B.; Pinnow, D.L.; Davis, J.; Raymer, P.; Pederson, G.A. A survey of the castor oil content, seed weight and seed-coat color on the United States Department of Agriculture germplasm collection. Plant Genet. Resour. C 2010, 8, 229-231. [CrossRef]

18. Gallardo, L.; Henríquez, A.; Thompson, A.M.; Rondanelli, R.; Carrasco, J.; Orfanoz-Cheuquelaf, A.; Velásquez, P. The first twenty years (1994-2014) of ozone soundings from Rapa Nui $\left(27^{\circ} \mathrm{S}, 109^{\circ} \mathrm{W}, 51\right.$ m.a.s.l.). Tellus B 2016, 68, 29484. [CrossRef]

19. Dirección Meteorológica de Chile. Anuario Meteorológico 2017; Dirección Meteorológica de Chile: Santiago, Chile, 2018; 104p. (In Spanish)

20. Falasca, S.L.; Ulberich, A.C.; Ulberich, E. Developing an agro-climatic zoning model to determine potential production areas for castor bean (Ricinus communis L.). Ind. Crop. Prod. 2012, 40, 185-191. [CrossRef]

21. Singer, S.D.; Zou, J.; Weselake, R.J. Abiotic factors influence plant storage lipid accumulation and composition. Plant Sci. 2016, 243, 1-9. [CrossRef]

22. Severino, L.S.; Auld, D.L. Study on the effect of air temperature on seed development and determination of the base temperature for seed growth in castor (Ricinus communis L.). Aust. J. Crop. Sci. 2014, 8, 290-295.

23. Piticar, A. Changes in agro-climatic indices related to temperature in Central Chile. Int. J. Biometeorol. 2019, 63, 499-510. [CrossRef] [PubMed]

24. Severino, L.S.; Auld, D.L.; Baldanzi, M.; Cândido, M.J.; Chen, G.; Crosby, W.; Tan, D.; He, X.; Lakshmamma, P.; Lavanya, C.; et al. A review of challenges for increased production of castor. Agron. J. 2012, 104, 853-880. [CrossRef]

25. Wang, M.L.; Morris, J.B.; Tonnis, B.; Pinnow, D.; Davis, J.; Raymer, P.; Pederson, G.A. Screening of the entire USDA castor germplasm collection for oil content and fatty acid composition for optimum biodiesel production. J. Agric. Food Chem. 2011, 59, 9250-9256. [CrossRef] [PubMed]

26. Da Silva, L.C.; Tango, J.S.; Savi, A.; Leal, N.R. Variability for oil and fatty acid composition in castorbean varieties. J. Am. Oil Chem. Soc. 1984, 61, 1841-1843. [CrossRef]

27. Christie, W.W.; Han, X. Lipid Analysis-Isolation, Separation, Identification and Lipidomic Analysis, 4th ed.; Woodhead Publishing Limited: Middlesex, UK, 2010; 428p.

28. Shah, S.K.; Patel, D.K.; Patel, R.M.; Patel, P.S.; Patel, D.U. Seed and quality characteristics in castor (Ricinus communis L.). J. Oilseeds Res. 2013, 30, 174-176. [CrossRef] 
29. Ramanjaneyulu, A.V.; Reddy, A.V.; Madhavi, A. The impact of sowing date and irrigation regime on castor (Ricinus communis L.) seed yield, oil quality characteristics and fatty acid composition during post rainy season in South India. Ind. Crop. Prod. 2013, 44, 25-31. [CrossRef]

30. Neto, S.S.O.; Manjavachi, M.K.P.; Zeffa, D.M.; Sartori, M.M.P.; Zanotto, M.D. Morphological characterization and selection of castor bean accessions for mechanized production. Pesqui. Agropecu. Trop. 2019, 49, e56749. [CrossRef]

31. Sturtevant, D.; Romsdahl, T.B.; Yu, X.-H.; Burks, D.J.; Azad, R.K.; Shanklin, J.; Chapman, K.D. Tissue-specific differences in metabolites and transcripts contribute to the heterogeneity of ricinoleic acid accumulation in Ricinus communis L. (castor) seeds. Metabolomics 2019, 15, 6. [CrossRef]

32. Venegas-Calerón, M.; Sánchez, R.; Salas, J.J.; Garcés, R.; Martínez-Force, E. Molecular and biochemical characterization of the OLE-1 high-oleic castor seed (Ricinus communis L.) mutant. Planta 2016, 244, 245-258. [CrossRef]

(C) 2020 by the authors. Licensee MDPI, Basel, Switzerland. This article is an open access article distributed under the terms and conditions of the Creative Commons Attribution (CC BY) license (http://creativecommons.org/licenses/by/4.0/). 